\title{
Determination of Seasonal Changes on Lipid Content and Fatty Acids of Nemipterus randalli (Russell, 1986) from Mersin Bay
}

\author{
Misra Bakan ${ }^{1, a}$, Nahit Soner Börekçi1,b,*, Deniz Ayas ${ }^{1, c}$ \\ ${ }^{1}$ Faculty of Fisheries, Mersin University, 33110 Mersin, Turkey \\ *Corresponding author
}

A R T I C L I N F O A B S T R A T

Research Article

In this study, the seasonal changes on lipid content and fatty acid levels of Nemipterus randalli from the Mersin Bay have been determined. Total lipid levels were found as $3.17 \%, 2.12 \%, 0.63 \%$, and $0.72 \%$ in spring, summer, autumn and winter seasons, respectively. The fatty acid composition of this species is composed of 30 fatty acids. Major fatty acids are palmitic acid (C16:0) and stearic

Received : 07/01/2020

Accepted : 07/06/2020 acid (C18:0) from saturated fatty acids (SFAs) oleic acid (C18:1n9c) and 11-docosenoic acid (ceteloic; C22:1n11) from monounsaturated fatty acids (MUFAs) and eicosapentaenoic acid (EPA; C20: 5n3), and docosahexaenoic acid (DHA; C22: 6n3) from polyunsaturated fatty acids (PUFAs). The highest level of palmitic acid was detected in the winter season, and the palmitic acid level varied between $15.41 \%$ and $20.72 \%(77.79-433.30 \mathrm{mg} / 100 \mathrm{~g})$. The highest level of stearic acid was determined in the spring season, and its levels varied between $14.75 \%$ and $19.14 \%$, and its levels

Keywords:

Nemipterus randalli

Lessepsian Species

Lipid

Fatty acids

Mersin Bay were also determined as 77.95-483.91 mg/100g. Oleic acid from the monounsaturated fatty acids varied between $5.46 \%$ and $7.98 \%$, and its levels were found to be $31.98-224.38 \mathrm{mg} / 100 \mathrm{~g}$. Ceteloic acid varied between $5.73 \%$ and $7.80 \%$, and its levels were determined to be $33.01-161.11 \mathrm{mg} / 100 \mathrm{~g}$. The EPA levels from the polyunsaturated fatty acids ranged from 4.34 to $5.34 \%$, and its levels were found to be 19.30-137.50 mg/100g. The highest levels of DHA were detected in autumn, its levels varied between $21.09 \%$ and $23.00 \%$, and its levels have also been detected as 102.30-604.25 $\mathrm{mg} / 100 \mathrm{~g}$. The highest levels of $\Sigma n 3, \Sigma n 6$ and $\Sigma n 9$ were found in the spring season. The levels of $\Sigma \mathrm{n} 3, \Sigma \mathrm{n} 6$ and $\Sigma \mathrm{n} 9$ varied between $26.73-27.19 \%(122.89-751.59 \mathrm{mg} / 100 \mathrm{~g}), 4.19-4.79 \%$ (18.63$134.68 \mathrm{mg} / 100 \mathrm{~g})$ and $5.95-9.79 \%(35.22-247.15 \mathrm{mg} / 100 \mathrm{~g})$, respectively. AI and TI values in $N$. randalli were found at $0.28-0.36 \%$ and $0.33-0.36 \%$, respectively.

\section{Introduction}

The Mediterranean Sea has started to show a tropical sea character with the effect of global physical factors such as; migration of Indo-Pacific species and global warming. Those species, which migrated to the Mediterranean Sea, encounter new physical, chemical, and biological conditions. While Lessepsian species cause to change in the Mediterranean ecosystem, they may also have some changes in themselves with the effect of these new conditions. Since the Eastern Mediterranean and the Red Sea have the same abiotic factors, Lessepsian species' feeding habits, habitats, and the depths that they disperse to find suitable areas for themselves have an acceleration effect on their migration (Golani, 2002).

While they usually prefer the areas that deeper than 120 meters, their juveniles are monitored up to 40 meters. The Nemipteridae genus's first individual in the Mediterranean,
Nemipterus randalli has been reported for the first time in 2005 in Israel, even though it was thought to be $N$. japonicas mistakenly (Golani and Sonin, 2006). This species, which is spread fastly all over the Eastern Mediterranean are found in schools and in the coastal areas where the sea ground is sandy and muddy, and the depth is between 5 to $80 \mathrm{~m}$. $N$. randalli is one of the common species that exist in the Red Sea and Suez Canal, and also has a significant population throughout the Indian Ocean and Western Pacific.

Lipids, alongside that they are one of the most important energy sources of the animals; they are very important in respect of their characteristics such as; containing the fat-soluble vitamins, forming the lipoproteins by dimerizing with the proteins and playing an essential role on the fat blood levels, forming the building 
blocks for the cell membrane by the fatty acids which are in their structure (Yücecan and Baykan, 1981). Eicosapentaenoic acid (EPA) and Docosahexaenoic acid (DHA), linolenic $\omega-3$ fatty acids, are found only within the sea products. These two, long-chain polyunsaturated fatty acids (PUFA), cause biochemical and physiological changes in the human body; meanwhile, they are very healthy for human consumption (Friedland, 2003).

Since the $\omega-3$ fatty acids are not synthesized within the human metabolism, those need to be taken through nutrition (Leaf \& Weber, 1988). The most important ones of $\omega-3$ fatty acids are EPA and DHA, and it is reported that their primary source is the sea products (Gordon et al., 1992). It is concluded from the studies about those fatty acids that they have essential roles protecting the human against health problems such as; heart attack, cardiovascular disease, depression, migraine-type headaches, articular rheumatism, diabetes, high cholesterol, and high blood pressure, some type of allergies and cancer (Gorga, 1988).

\section{Materials and Methods}

N. randalli (Russell, 1986) specimens were caught by trawlers between the dates of March 2016, September 2016, and December 2016 and by trammel net in June 2016. In each season and from each species, 30 individuals were ensampled, which makes 120 individuals in total for four seasons. All specimens' length and weight averages were calculated.

$N$. randalli's seasonal length range is between 15.66$19.00 \mathrm{~cm}$, and its weight ranges between 55.75-87.00 gr. (Table 1).

\section{Fat and Fatty Acids Analyses}

Lipid analysis was performed using the Bligh \& Dyer (1959) method. In extracted lipids, fatty acid methyl esters were obtained using the Ichibara et al. (1996) method. The fatty acid composition was analyzed using a Gas Chromatography (GC) Clarus 500 device (Perkin-Elmer, USA), one flame ionization detector (FID), and SGE (60 m $\times 0.32 \mu \mathrm{mm}$ ID BPX70 $\times 0.25 \mu \mathrm{m}$, USA or Australia) column. Injector and detector temperatures were set as $260^{\circ} \mathrm{C}$ and $230^{\circ} \mathrm{C}$, respectively. During this time, the furnace temperature was kept at $140^{\circ} \mathrm{C}$ for 8 minutes. After that, it was increased by $4^{\circ} \mathrm{C}$ per minute until $220^{\circ} \mathrm{C}$, and from $220^{\circ} \mathrm{C}$ to $230^{\circ} \mathrm{C}$ by increasing the temperature $1^{\circ} \mathrm{C}$ per minute. It was kept at $230^{\circ} \mathrm{C}$ for 15 minutes to complete the analysis. The sample scale was $1 \mu 1$, and carrier gas was controlled at $16 \mathrm{ps}$. For split-flow 40, $0 \mathrm{~mL} /$ minute (1:40) level was used. Fatty acids were determined using a comparison to the exit times of the FAME mix that contains 37 standard components.

\section{Conversion Factor}

Triplicate GC analyses were performed, and the results were converted to $\mathrm{mg}$ fatty acid per $100 \mathrm{~g}$ total lipid using lipid conversion factors and then to $\mathrm{mg}$ fatty acid per 100 $\mathrm{g}$ edible portion of food using the total lipid content. Details of the derivation of lipid conversion factors were published by Weihrauch et al. (1975).

$$
\begin{array}{ll}
\mathrm{F} & =0.956-0.143 / \mathrm{TL} \\
\mathrm{FA} & =\mathrm{F} \times \mathrm{FAME}(\%) \times \mathrm{LL} \times 10
\end{array}
$$

Where;

$\mathrm{F} \quad=$ Factor (Fish)

$\mathrm{TL}=$ Total Lipid

LL = Lipid Level

Atherogenicity Index (AI) and Thrombogenicity Index (TI)

The AI and TI linked to the fatty acid composition were calculated according to Ulbricht and Southgate (1991).

$$
\left.\mathrm{AI}=\frac{[(\mathrm{a} \times 12: 0)+(\mathrm{b} \times 14: 0)+(\mathrm{c} \times 16: 0)]}{[\mathrm{d} \times(\text { PUFA } n-6+n-3)+\mathrm{e} \times(\text { MUFA })+\mathrm{f} \times(\text { MUFA-18:1) }}\right]
$$

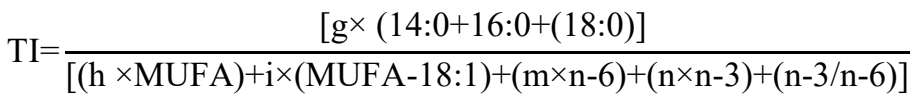

$$
\text { a, c, d, e, f=1, b=4, g=1, h, i, m=0.5 n=3 }
$$

\section{Statistical Analysis}

Prior to the analyses, all data were checked for outliers, and homogeneity of variance was also tested. Statistical analysis of data was carried out with the IBM SPSS STATISTICS 22 statistical program. ANOVA (Analysis of Variance) was used to evaluate the effect of age on the metals levels.

Table 1. Length and weight of $N$. randalli

\begin{tabular}{l|ccc}
\hline \multicolumn{1}{c|}{ Season } & $\mathrm{N}$ & Mean TL $(\mathrm{cm}) \overline{\mathrm{X}} \pm \mathrm{S}_{\mathrm{x}}$ & Mean Weight $(\mathrm{g}) \overline{\mathrm{X}} \pm \mathrm{S}_{\mathrm{x}}$ \\
\hline Spring & 30 & $16.03 \pm 0.28^{\mathrm{x}}$ & $61.38 \pm 2.21^{\mathrm{a}}$ \\
Summer & 30 & $15.66 \pm 0.56^{\mathrm{x}}$ & $55.75 \pm 5.29^{\mathrm{a}}$ \\
Autumn & 30 & $19.00 \pm 0.23^{\mathrm{y}}$ & $87.00 \pm 2.28^{\mathrm{b}}$ \\
Winter & 30 & $17.00 \pm 0.36^{\mathrm{x}}$ & $76.75 \pm 5.00^{\mathrm{b}}$ \\
\hline
\end{tabular}

The values on the same line, shown in different letters, are statistically different $(\mathrm{P}<0.05)$, TL: total length, $\mathrm{W}$ : weight , $\overline{\mathrm{X}} \pm \mathrm{S}_{\mathrm{x}}$ mean \pm Standart deviation

\section{Results}

The total lipid levels of $N$. randalli were changed between $0.63 \%$ and $3.17 \%$, and the highest lipid levels were found in the spring season. A statistical difference was observed between the autumn and winter seasons and the other two seasons $(\mathrm{P}<0.05)$ (Table 2$)$.

\section{Fatty acid Levels (\%)}

It was determined that the fatty acid profile was composed of 30 fatty acids. These fatty acids are lauric acid (C12:0), myristic acid (C14:0), pentadecanoic acid (C15:0), palmitic acid (C16:0), heptadecanoic acid (C17:0), stearic acid (C18:0), arachidic acid (C20:0), 
behenic acid (C22:0), trichosanoic acid (C23:0), lignosuric acid (C24:0), myristoleic acid (C14:1), pentadecenoic acid (C15:1), palmitoleic acid (C16:1), heptadecenoic acid $(\mathrm{C} 17: 1)$, oleic acid $(\mathrm{C} 18: 1 n 9 \mathrm{t})$, oleic acid $(\mathrm{C} 18: 1 n 9 \mathrm{c})$, vacceneic acid (C18:1n7), gadoleic acid (C20:1n9), cetoleic acid (C22: $1 n 11)$, nervonic acid $(\mathrm{C} 24: 1 n 9)$, linoleic acid $(\mathrm{C} 18: 2 n 6 \mathrm{t})$, linoleic acid $(\mathrm{C} 18: 2 n 6 \mathrm{c})$, alfa linolenic (C18:3n3), gamma linolenic (C18:3n6), eicosatrienoic acid (C20:3n3), eicosatrienoic acid (C20:3n6), arachidonic acid (C20:4n6), eikosapentaenoic acid (C20:5n3), docosahexaenoic acid (C22:6n3), Cetoloic acid (C22:2cis) (Table 3).

N. randalli's dominant SFAs (saturated fatty acids) are palmitic acid and stearic acid, MUFAs (monounsaturated fatty acids) are oleic acid and cetoleic acid, PUFAs (polyunsaturated fatty acids) are EPA and DHA fatty acids (Table 3).

Table 2. Lipid changes of N. randalli $(\%)$

\begin{tabular}{l|cccc}
\hline & Spring $\overline{\mathrm{X}} \pm \mathrm{S}_{\mathrm{x}}$ & Summer $\overline{\mathrm{X}} \pm \mathrm{S}_{\mathrm{x}}$ & Autumn $\overline{\mathrm{X}} \pm \mathrm{S}_{\mathrm{x}}$ & Winter $\overline{\mathrm{X}} \pm \mathrm{S}_{\mathrm{x}}$ \\
\hline$\%$ Total lipid & $3.17 \pm 0.47^{\mathrm{b}}$ & $2.12 \pm 0.35^{\mathrm{b}}$ & $0.63 \pm 0.04^{\mathrm{a}}$ & $0.72 \pm 0.06^{\mathrm{a}}$ \\
\hline \multicolumn{7}{l}{ The values on the same line, shown in different letters, are statistically different $(\mathrm{P}<0.05)$, TL: total length $\mathrm{W} \cdot$ weight $\overline{\mathrm{X}} \pm \mathrm{S}_{\mathrm{x}}$ mean \pm Standart deviation }
\end{tabular}

The values on the same line, shown in different letters, are statistically different $(\mathrm{P}<0.05)$, TL: total length, $\mathrm{W}:$ weight,$\overline{\mathrm{X}} \pm \mathrm{S}_{\mathrm{x}}$ mean \pm Standart deviation

Table 3. Fatty acids profiles of N. randalli $(\%)$

\begin{tabular}{|c|c|c|c|c|}
\hline Fatty acids (\%) & Spring $\bar{X} \pm S_{x}$ & Summer $\overline{\mathrm{X}} \pm \mathrm{S}_{\mathrm{x}}$ & Autumn $\overline{\mathrm{X}} \pm \mathrm{S}_{\mathrm{x}}$ & Winter $\overline{\mathrm{X}} \pm \mathrm{S}_{\mathrm{x}}$ \\
\hline Lauric acid (C12:0) & $0.42 \pm 0.06^{\mathrm{b}}$ & $0.41 \pm 0.08^{\mathrm{b}}$ & $0.44 \pm 0.08^{\mathrm{b}}$ & $0.25 \pm 0.00^{\mathrm{a}}$ \\
\hline Myristic acid (C14:0) & $1.42 \pm 0.23^{\mathrm{b}}$ & $0.67 \pm 0.09^{\mathrm{a}}$ & $0.73 \pm 0.04^{\mathrm{a}}$ & $0.91 \pm 0.22^{\mathrm{a}}$ \\
\hline Pentadecylic acid (C15:0) & $0.53 \pm 0.01^{\mathrm{a}}$ & $0.53 \pm 0.05^{\mathrm{a}}$ & $0.44 \pm 0.00^{\mathrm{a}}$ & $0.54 \pm 0.07^{\mathrm{a}}$ \\
\hline Palmitic acid (C16:0) & $15.41 \pm 0.47^{\mathrm{a}}$ & $16.47 \pm 0.83^{\mathrm{a}}$ & $17.49 \pm 0.23^{\mathrm{ab}}$ & $20.72 \pm 3.15^{\mathrm{b}}$ \\
\hline Margaric acid (C17:0) & $0.94 \pm 0.05^{\mathrm{a}}$ & $0.94 \pm 0.07^{\mathrm{a}}$ & $0.86 \pm 0.02^{\mathrm{a}}$ & $0.98 \pm 0.08^{\mathrm{a}}$ \\
\hline Stearic acid $(\mathrm{C} 18: 0)$ & $17.21 \pm 0.23^{\mathrm{ab}}$ & $16.67 \pm 1.34^{\mathrm{ab}}$ & $19.14 \pm 0.04^{\mathrm{b}}$ & $14.75 \pm 1.79^{a}$ \\
\hline Arachidic acid (C20:0) & $0.51 \pm 0.01^{\mathrm{b}}$ & $0.39 \pm 0.04^{\mathrm{a}}$ & $0.46 \pm 0.03^{\mathrm{ab}}$ & $0.36 \pm 0.02^{\mathrm{a}}$ \\
\hline Behenic acid (C22:0) & $0.00 \pm 0.00^{\mathrm{a}}$ & $0.00 \pm 0.00^{\mathrm{a}}$ & $0.00 \pm 0.00^{\mathrm{a}}$ & $0.00 \pm 0.00^{\mathrm{a}}$ \\
\hline Lignoceric acid (C24:0) & $2.81 \pm 0.11^{\mathrm{a}}$ & $3.26 \pm 0.20^{\mathrm{b}}$ & $3.05 \pm 0.00^{\mathrm{ab}}$ & $2.77 \pm 0.23^{\mathrm{a}}$ \\
\hline$\Sigma$ SFA & 39.25 & 39.34 & 42.61 & 41.28 \\
\hline Myristoleic acid (C14:1) & $0.00 \pm 0.00^{\mathrm{a}}$ & $0.00 \pm 0.00^{\mathrm{a}}$ & $0.00 \pm 0.00^{\mathrm{a}}$ & $0.00 \pm 0.00^{\mathrm{a}}$ \\
\hline Pentadecenoic (C15:1) & $0.00 \pm 0.00^{\mathrm{a}}$ & $0.00 \pm 0.00^{\mathrm{a}}$ & $0.00 \pm 0.00^{\mathrm{a}}$ & $0.00 \pm 0.00^{\mathrm{a}}$ \\
\hline Palmitoleic acid (C16:1) & $3.31 \pm 0.18^{\mathrm{b}}$ & $1.91 \pm 0.20^{\mathrm{a}}$ & $1.80 \pm 0.12^{\mathrm{a}}$ & $1.94 \pm 0.27^{\mathrm{a}}$ \\
\hline Heptadecenoic acid (C17:1) & $0.41 \pm 0.06^{\mathrm{a}}$ & $0.39 \pm 0.04^{\mathrm{a}}$ & $0.37 \pm 0.02^{\mathrm{a}}$ & $0.38 \pm 0.04^{\mathrm{a}}$ \\
\hline Trans oleic acid (C18:1n9t) & $0.11 \pm 0.16^{\mathrm{b}}$ & $0.00 \pm 0.00^{\mathrm{a}}$ & $0.00 \pm 0.00^{\mathrm{a}}$ & $0.00 \pm 0.00^{\mathrm{a}}$ \\
\hline Oleic acid $(\mathrm{C} 18: 1 n 9 \mathrm{c})$ & $7.98 \pm 0.55^{\mathrm{b}}$ & $5.46 \pm 0.35^{\mathrm{a}}$ & $7.19 \pm 0.06^{\mathrm{ab}}$ & $6.20 \pm 0.63^{\mathrm{ab}}$ \\
\hline Vaccenic acid $(\mathrm{C} 18: 1 n 7)$ & $2.12 \pm 0.06^{\mathrm{a}}$ & $1.86 \pm 0.14^{\mathrm{a}}$ & $1.77 \pm 0.06^{\mathrm{a}}$ & $1.98 \pm 0.13^{\mathrm{a}}$ \\
\hline Gadoleic acid (C20:1n9) & $0.49 \pm 0.06^{\mathrm{b}}$ & $0.28 \pm 0.03^{\mathrm{a}}$ & $0.36 \pm 0.01^{\mathrm{a}}$ & $0.52 \pm 0.07^{\mathrm{b}}$ \\
\hline Cetoloic acid (C22:1n11) & $5.73 \pm 0.33^{\mathrm{a}}$ & $7.80 \pm 0.44^{\mathrm{b}}$ & $7.49 \pm 0.30^{\mathrm{b}}$ & $7.56 \pm 0.51^{\mathrm{b}}$ \\
\hline Nervonic acid (C24:1n9) & $0.21 \pm 0.05^{\mathrm{b}}$ & $0.21 \pm 0.01^{\mathrm{b}}$ & $0.30 \pm 0.01^{\mathrm{b}}$ & $0.00 \pm 0.00^{\mathrm{a}}$ \\
\hline$\Sigma$ MUFA & 20.36 & 17.91 & 19.28 & 18.58 \\
\hline Linolelaidic Acid (C18:2n6t) & $0.07 \pm 0.09^{\mathrm{b}}$ & $0.00 \pm 0.00^{\mathrm{a}}$ & $0.00 \pm 0.00^{\mathrm{a}}$ & $0.00 \pm 0.00^{\mathrm{a}}$ \\
\hline Linoleic acid (C18:2n6c) & $1.60 \pm 0.22^{\mathrm{b}}$ & $1.22 \pm 0.11^{\mathrm{a}}$ & $1.40 \pm 0.06^{\mathrm{ab}}$ & $1.45 \pm 0.04^{\mathrm{ab}}$ \\
\hline$\alpha$-Linolenic acid $(\mathrm{C} 18: 3 n 3)$ & $0.08 \pm 0.11^{\mathrm{b}}$ & $0.00 \pm 0.00^{\mathrm{a}}$ & $0.00 \pm 0.00^{\mathrm{a}}$ & $0.00 \pm 0.00^{\mathrm{a}}$ \\
\hline Gamma linolenic acid (C18:3n6) & $0.09 \pm 0.12^{\mathrm{b}}$ & $0.08 \pm 0.11^{\mathrm{b}}$ & $0.00 \pm 0.00^{\mathrm{a}}$ & $0.00 \pm 0.00^{\mathrm{a}}$ \\
\hline Eicosatrienoic acid $(\mathrm{C} 20: 3 n 3)$ & $0.27 \pm 0.00^{\mathrm{b}}$ & $0.30 \pm 0.02^{b}$ & $0.29 \pm 0.02^{\mathrm{b}}$ & $0.11 \pm 0.16^{\mathrm{a}}$ \\
\hline Dihomo- $\gamma$-linolenic acid $(\mathrm{C} 20: 3 n 6)$ & $0.33 \pm 0.02^{\mathrm{c}}$ & $0.24 \pm 0.02^{b}$ & $0.00 \pm 0.00^{\mathrm{a}}$ & $0.22 \pm 0.01^{\mathrm{b}}$ \\
\hline Arachidonic acid (C20:4n6) & $0.39 \pm 0.01^{\mathrm{a}}$ & $0.40 \pm 0.03^{\mathrm{a}}$ & $0.36 \pm 0.04^{\mathrm{a}}$ & $0.33 \pm 0.02^{\mathrm{a}}$ \\
\hline Eicosapentaenoic acid (C20:5n3) & $4.89 \pm 0.14^{\mathrm{ab}}$ & $5.34 \pm 0.18^{b}$ & $4.34 \pm 0.13^{\mathrm{a}}$ & $5.08 \pm 0.33^{b}$ \\
\hline Adrenic acid $(\mathrm{C} 22: 4 n 6)$ & $2.31 \pm 0.20^{\mathrm{a}}$ & $2.26 \pm 0.14^{\mathrm{a}}$ & $2.43 \pm 0.01^{\mathrm{a}}$ & $2.71 \pm 0.09^{b}$ \\
\hline Docosahexaenoic acid (C22:6n3) & $21.49 \pm 0.02^{\mathrm{a}}$ & $21.09 \pm 1.39^{\mathrm{a}}$ & $23.00 \pm 0.67^{\mathrm{a}}$ & $22.00 \pm 1.87^{\mathrm{a}}$ \\
\hline Docosadienoic acid (C22:2n6) & $0.31 \pm 0.04^{\mathrm{c}}$ & $0.15 \pm 0.01^{\mathrm{b}}$ & $0.00 \pm 0.00^{\mathrm{a}}$ & $0.00 \pm 0.00^{\mathrm{a}}$ \\
\hline SPUFA & 31.83 & 31.08 & 31.82 & 31.90 \\
\hline PUFA /SFA & 0.81 & 0.79 & 0.75 & 0.77 \\
\hline$\sum n 6$ & 4.79 & 4.20 & 4.19 & 4.71 \\
\hline$\Sigma n 3$ & 26.73 & 26.73 & 27.63 & 27.19 \\
\hline$\Sigma n 7$ & 2.12 & 1.86 & 1.77 & 1.98 \\
\hline$\Sigma n 9$ & 8.79 & 5.95 & 7.85 & 6.72 \\
\hline$\Sigma n 11$ & 5.73 & 7.80 & 7.49 & 7.56 \\
\hline$n 6 / n 3$ & 0.18 & 0.16 & 0.15 & 0.17 \\
\hline$n 3 / n 6$ & 5.58 & 6.36 & 6.59 & 5.77 \\
\hline DHA/EPA & 4.39 & 3.95 & 5.30 & 4.33 \\
\hline $\mathrm{AI}$ & 0.28 & 0.30 & 0.30 & 0.36 \\
\hline $\mathrm{TI}$ & 0.35 & 0.33 & 0.36 & 0.35 \\
\hline Unidentified & 8.56 & 10.67 & 6.29 & 8.24 \\
\hline
\end{tabular}

The values on the same line, shown in different letters, are statistically different $(\mathrm{P}<0.05)$, TL: total length, $\mathrm{W}$ : weight , $\overline{\mathrm{X}} \pm \mathrm{S}_{\mathrm{x}}$ mean \pm Standart deviation 
$\Sigma$ SFA, $\Sigma$ MUFA, and $\Sigma$ PUFA levels are calculated to be $39.25 \%-42.61 \%, 17.91 \%-20.36 \%, 31.08 \%-31.90 \%$, respectively.

Lauric acid is one of the saturated fatty acids, and its levels in winter and other seasons were determined $(\mathrm{P}<0.05)$ in respect of their statistical differences. The lowest value was in winter by $(0.25 \%)$, the highest was in autumn $(0.44 \%)$. There was a statistical difference between the myristic acid levels in spring and its levels in other seasons $(\mathrm{P}<0.05)$. While the lowest value was seen in summer $(0.67 \%)$, the highest value was in spring $(1.42 \%)$. Furthermore, there were no differences between the pentadecylic acid levels in all seasons $(\mathrm{P}>0.05)$. The fatty acid levels were between $0.44-0.54 \%$ during four seasons. There were some differences between palmitic acid levels in winter, spring, and summer $(\mathrm{P}<0.05)$. While the highest value was in winter $(20.72 \%)$, the lowest value was in spring $(15.41 \%)$. There were no differences between heptadecenoic acid levels in all seasons $(\mathrm{P}>0.05)$. This fatty acid's levels were in the range of $0.37-0.41 \%$. However, there were differences between stearic acid levels in winter and autumn $(\mathrm{P}<0.05)$. The lowest value was in winter $(14.75 \%)$, and the highest value was in autumn (19.14\%). There were differences between arachidic acid levels in winter, summer, and spring. While the lowest value was in winter $(0.36 \%)$, the highest value was in spring $(0.51 \%)$. Behenic acid levels were under the detection limits in all seasons. There were differences between lignoceric acid levels in summer, spring and winter $(\mathrm{P}<0.05)$. The highest value was in summer $(3.26 \%)$; the lowest was in winter $(2.77 \%)$.

Myristoleic and pentadecenoic acids are monounsaturated fatty acids, and their levels were under detection limits in all seasons. Palmitoleic acid levels in spring were different from the other seasons $(\mathrm{P}<0.05)$. The highest value was in spring $(3.31 \%)$, the lowest was in autumn $(1.80 \%)$. Moreover, there were no differences between heptadecenoic acid levels in all seasons $(\mathrm{P}>0.05)$. Trans oleic acid (C18:1n9t) levels in spring were $0.11 \%$; in other seasons, they were below the detection limits $(\mathrm{P}<0.05)$. There were differences in oleic acid $(\mathrm{C} 18: 1 \mathrm{n} 9 \mathrm{c})$ levels in summer and spring $(\mathrm{P}<0.05)$. While the highest value was in spring $(7.98 \%)$, the lowest was in summer $(5.46 \%)$. There were no differences between vaccenic acid levels $(\mathrm{P}>0.05)$. Its levels were in the range of $1.77-2.12 \%$. There were differences between gadoleic acid levels in summer-autumn and spring-winter seasons $(\mathrm{P}<0.05)$. While this fatty acid has low levels in summer and autumn $(0.28-0.36 \%)$, high levels were in spring and winter $(0.49$ $0.52 \%)$. There were differences between cetoloic acid levels in spring and in other seasons $(\mathrm{P}<0.05)$. While the lowest value was in spring $(5.73 \%)$, the highest was in summer $(7.80 \%)$. There were differences between nervonic acid levels in winter and in other seasons $(\mathrm{P}<0.05)$. This fatty acid's highest levels were in autumn $(0.30 \%)$

One of $N$. randalli's polyunsaturated fatty acids is linolelaidic acid (C18:2n6t), and it was above the detection limits only in spring $(\mathrm{P}<0.05)$. It was found at $0.07 \%$. However, there were differences between linoleic acid $(\mathrm{C} 18: 2 \mathrm{n} 6 \mathrm{c})$ levels in spring and summer $(\mathrm{P}<0.05)$. While this fatty acid's lowest value was in summer $(1.22 \%)$, the highest was in spring (1.60\%). Alfa linoleic acid level was above the detection limits only in spring $(\mathrm{P}<0.05)$. It was found at $0.08 \%$. Gamma linoleic acid levels in spring and summer were above the detection limits. This fatty acid's highest value was in spring $(0.09 \%)$. Eicosatrienoic acid $(\mathrm{C} 20: 3 \mathrm{n} 3)$ levels in winter were different from other seasons $(\mathrm{P}<0.05)$. While this fatty acid's lowest value was in winter $(0.11 \%)$, the highest level was in summer $(0.30 \%)$. Though there were no differences between dihomo- $\gamma$-linolenic acid (C20:3n6) levels in summer and winter $(\mathrm{P}>0.05)$, there were statistical differences in these two seasons (summer and winter) and other seasons $(\mathrm{P}<0.05)$. This fatty acid's highest value was in spring $(0.33 \%)$. There were no differences between arachidonic acid $(\mathrm{C} 20: 4 n 6)$ levels in all seasons $(\mathrm{P}>0.05)$. This fatty acid's levels were in the range of $0.33-0.40 \%$. There were statistical differences between eicosapentaenoic acid levels in autumn and summer-winter $(\mathrm{P}<0.05)$. While the lowest value was in autumn $(4.34 \%)$, the highest was in summer $(5.34 \%)$. There were differences between adrenic acid $(\mathrm{C} 22: 4 n 6)$ levels in winter and other seasons $(\mathrm{P}<0.05)$. This fatty acid's highest value was in winter by $2.71 \%$; the lowest was in summer $(2.26 \%)$. There were no statistical differences between docosahexaenoic acid levels in all seasons $(\mathrm{P}>0.05)$. This fatty acid's highest value was in autumn $(23.00 \%)$. There were statistical differences in docosadienoic acid (C22:2cis) levels in all seasons $(\mathrm{P}<0.05)$. This fatty acid's lowest value was in summer $(0.15 \%)$, and the highest was in spring $(0.31 \%)$. However, fatty acid levels during the other two seasons couldn't have been detected.

$N$. randalli's $\Sigma n 3, \Sigma n 6, \Sigma n 9$ fatty acid levels range between $26.73-27.63 \%, 4.19-4.79 \%$, and $5.95-8.79 \%$ respectively. Highest $\Sigma n 6$ and $\Sigma n 9$ levels were in spring. During the year, $\mathrm{Ai}$ and $\mathrm{Ti}$ levels range between 0.28 $0.36 \%, 0.33-0.36 \%$, respectively.

\section{Fatty acid Levels (mg/100g)}

The changes in fatty acid levels of $N$. randalli according to different age groups are given in Table 4 as $\mathrm{mg} / 100 \mathrm{~g}$.

$N$. randalli's saturated (SFA), monounsaturated (MUFA) and polyunsaturated (PUFA) fatty acid levels range between 189.52-1103.62 $\mathrm{mg} / 100 \mathrm{~g}$, 85.45-572.51 $\mathrm{mg} / 100 \mathrm{~g}$, and $141.52-894.99 \mathrm{mg} / 100 \mathrm{~g}$ respectively during the year. The highest saturated fatty acid ( $\Sigma$ SFA) level was in spring, and the lowest was in autumn. The lowest monounsaturated ( $\mathrm{M}$ MUFA) and polyunsaturated ( PUFA) fatty acid levels were in autumn, and the highest was in spring.

One of the saturated fatty acids, lauric acid, its levels in spring, summer, autumn, and winter was $11.81 \mathrm{mg} / 100 \mathrm{~g}$, $7.52 \mathrm{mg} / 100 \mathrm{~g}, \quad 1.96 \mathrm{mg} / 100 \mathrm{~g}$, and $1.32 \mathrm{mg} / 100 \mathrm{~g}$ respectively. The lowest myristic acid level was in autumn $(3.25 \mathrm{mg} / 100 \mathrm{~g})$, and the highest was in spring (39.93) $\mathrm{mg} / 100 \mathrm{~g}$. While palmitic acid levels in spring, summer, autumn and winter were $433.30 \mathrm{mg} / 100 \mathrm{~g}, 302.02 \mathrm{mg} / 100 \mathrm{~g}$, $77.79 \mathrm{mg} / 100 \mathrm{~g}$ and $109.50 \mathrm{mg} / 100 \mathrm{~g}$ respectively, stearic acid levels were $483.91 \mathrm{mg} / 100 \mathrm{~g}, 305.69 \mathrm{mg} / 100 \mathrm{~g}, 85.13$ $\mathrm{mg} / 100 \mathrm{~g}$ and $77.95 \mathrm{mg} / 100 \mathrm{~g}$ respectively. The highest levels for palmitic and stearic acids were both in spring. The lowest palmitic acid level was in autumn, and the lowest stearic acid level was in winter. The highest lignoceric acid level was in spring; the lowest was in autumn. 
Table 4. Fatty acids profiles of $N$. randalli $(\mathrm{mg} / 100 \mathrm{~g})$

\begin{tabular}{|c|c|c|c|c|}
\hline Total lipid \% & 3.17 & 2.12 & 0.63 & 0.72 \\
\hline Factor & 0.887 & 0.865 & 0.706 & 0.734 \\
\hline Fatty acids (mg/100g) & Spring & Summer & Autumn & Winter \\
\hline Lauric acid (C12:0) & 11.81 & 7.52 & 1.96 & 1.32 \\
\hline Myristic acid (C14:0) & 39.93 & 12.29 & 3.25 & 4.81 \\
\hline Pentadecylic acid (C15:0) & 14.9 & 9.72 & 1.96 & 2.85 \\
\hline Palmitic acid (C16:0) & 433.30 & 302.02 & 77.79 & 109.50 \\
\hline Margaric acid (C17:0) & 26.43 & 17.23 & 3.83 & 5.18 \\
\hline Stearic acid (C18:0) & 483.91 & 305.69 & 85.13 & 77.95 \\
\hline Arachidic acid (C20:0) & 14.34 & 7.15 & 2.05 & 1.90 \\
\hline Behenic acid (C22:0) & 0.00 & 0.00 & 0.00 & 0.00 \\
\hline Lignoceric acid (C24:0) & 79.01 & 59.78 & 13.57 & 14.64 \\
\hline$\Sigma$ SFA & 1103.62 & 721.41 & 189.52 & 218.15 \\
\hline Myristoleic acid (C14:1) & 0.00 & 0.00 & 0.00 & 0.00 \\
\hline Pentadecenoic (C15:1) & 0.00 & 0.00 & 0.00 & 0.00 \\
\hline Palmitoleic acid (C16:1) & 93.10 & 35.03 & 8.01 & 10.25 \\
\hline Heptadecenoic acid (C17:1) & 11.53 & 7.15 & 1.65 & 2.01 \\
\hline Trans oleic acid (C18:1n9t) & 3.10 & 0.00 & 0.00 & 0.00 \\
\hline Oleic acid $(\mathrm{C} 18: \ln 9 \mathrm{c})$ & 224.38 & 100.13 & 31.98 & 32.77 \\
\hline Vaccenic acid (C18:1n7) & 59.61 & 34.11 & 7.87 & 10.46 \\
\hline Gadoleic acid (C20:1n9) & 13.78 & 5.13 & 1.60 & 2.75 \\
\hline Cetoloic acid (C22:1n11) & 161.11 & 143.04 & 33.01 & 39.95 \\
\hline Nervonic acid (C24:1n9) & 5.90 & 3.85 & 1.33 & 0.00 \\
\hline$\Sigma$ MUFA & 572.51 & 328.44 & 85.45 & 98.19 \\
\hline Linolelaidic Acid (C18:2n6t) & 1.97 & 0.00 & 0.00 & 0.00 \\
\hline Linoleic acid (C18:2n6c) & 44.99 & 22.37 & 6.23 & 7.66 \\
\hline$\alpha$-Linolenic acid (C18:3n3) & 2.25 & 0.00 & 0.00 & 0.00 \\
\hline Gamma linolenic acid (C18:3n6) & 2.53 & 1.47 & 0.00 & 0.00 \\
\hline Eicosatrienoic acid (C20:3n3) & 7.59 & 5.50 & 1.29 & 0.58 \\
\hline Dihomo- $\gamma$-linolenic acid (C20:3n6) & 9.28 & 4.40 & 0.00 & 1.16 \\
\hline Arachidonic acid (C20:4n6) & 10.97 & 7.34 & 1.60 & 1.74 \\
\hline Eicosapentaenoic acid (C20:5n3) & 137.50 & 97.92 & 19.30 & 26.85 \\
\hline Adrenic acid (C22:4n6) & 64.95 & 41.44 & 10.80 & 14.32 \\
\hline Docosahexaenoic acid (C22:6n3) & 604.25 & 386.75 & 102.30 & 116.26 \\
\hline Docosadienoic acid (C22:2n6) & 8.72 & 2.75 & 0.00 & 0.00 \\
\hline$\Sigma$ PUFA & 894.99 & 569.94 & 141.52 & 168.58 \\
\hline$\Sigma n 6$ & 134.68 & 77.01 & 18.63 & 24.89 \\
\hline$\Sigma n 3$ & 751.59 & 490.17 & 122.89 & 143.69 \\
\hline$\Sigma n 9$ & 247.15 & 109.11 & 35.22 & 35.52 \\
\hline$\sum n 11$ & 161.11 & 143.04 & 33.01 & 39.95 \\
\hline$\sum n 7$ & 59.61 & 34.11 & 7.87 & 10.46 \\
\hline Unidentified & 240.68 & 214.00 & 27.98 & 43.55 \\
\hline
\end{tabular}

One of the monounsaturated fatty acids, palmitoleic acid, and its levels in spring, summer, autumn, and winter were $93.10 \mathrm{mg} / 100 \mathrm{~g}, 35.03 \mathrm{mg} / 100 \mathrm{~g}, 8.01 \mathrm{mg} / 100 \mathrm{~g}$, and $10.25 \mathrm{mg} / 100 \mathrm{~g}$ respectively. The highest oleic acid (C18:1n9c) level was in spring by $224.38 \mathrm{mg} / 100 \mathrm{~g}$; the lowest was in spring and summer (31.98-32.77 mg/100g). The highest vaccenic acid level was in spring (59.61 $\mathrm{mg} / 100 \mathrm{~g})$; the lowest was in autumn $(7.87 \mathrm{mg} / 100 \mathrm{~g})$. The highest gadoleic acid level was in spring $(13.78 \mathrm{mg} / 100 \mathrm{~g})$; the lowest was in autumn $(1.60 \mathrm{mg} / 100 \mathrm{~g})$. Cetoloic acid is one of the monounsaturated fatty acids (MUFA), and its levels in spring, summer, autumn and winter were 161.11 $\mathrm{mg} / 100 \mathrm{~g}, 143.04 \mathrm{mg} / 100 \mathrm{~g}, 33.01 \mathrm{mg} / 100 \mathrm{~g}$ and 39.95 $\mathrm{mg} / 100 \mathrm{~g}$, respectively. The highest nervonic acid level was in spring $(5.90 \mathrm{mg} / 100 \mathrm{~g})$.

Polyunsaturated fatty acid (PUFA) levels, in spring, summer, autumn, and winter were $890.99 \mathrm{mg} / 100 \mathrm{~g}, 569.94$ $\mathrm{mg} / 100 \mathrm{~g}, \quad 141.52 \mathrm{mg} / 100 \mathrm{~g}$, and $168.58 \mathrm{mg} / 100 \mathrm{~g}$, respectively. Linoleic acid (C18:2n6c), eicosatrienoic acid (C20:3n3), eicosatrienoic acid (C20:3n6), and arachidonic acid belong to polyunsaturated fatty acids (PUFA), and their levels range between $6.23-44.99 \mathrm{mg} / 100 \mathrm{~g}, 0.58-7.59$ $\mathrm{mg} / 100 \mathrm{~g}, \quad 0.00-9.28 \mathrm{mg} / 100 \mathrm{~g}, \quad 1.60-10.97 \mathrm{mg} / 100 \mathrm{~g}$ respectively.

The highest eicosapentaenoic acid (EPA) and docosahexaenoic acid (DHA) levels were in spring; the lowest was in autumn. EPA levels were in the range of $19.30-137.50 \mathrm{mg} / 100 \mathrm{~g}$, DHA levels were in the range of 102.30-604.25 mg/100g during the year.

$N$. randalli's $\Sigma n 3, \Sigma n 6, \Sigma n 9$ fatty acid levels were in the range of $122.89-751.59 \mathrm{mg} / 100 \mathrm{~g}, 18.63-134.68 \mathrm{mg} / 100 \mathrm{~g}$, $35.22-247.15 \mathrm{mg} / 100 \mathrm{~g}$. Highest $\Sigma n 3, \Sigma n 6, \Sigma n 9$ levels were found in spring. 


\section{Discussion}

Lambertsen (1998) described fish with 2-4\% fat as lowfat fish. In our study, the total lipid change range of $N$. randalli was found to be $0.63-3.17 \%$. When the total lipid level of the given scale was evaluated, it was determined that $N$. randalli is low-fat fish.

Nazeer et al. (2008) had investigated Nemipterus japonicus's fatty acid profile, and the sampling was made in winter. The total lipid level of $N$. japonicus in Nazeer et al. (2008)'s study was $2.70 \%$. That result shows both $N$. japonicus and $N$. randalli (present study) have similar total lipid levels. Moreover, on the muscle tissue of $N$. japonicus in Nazeer et al. (2008)'s study, the palmitic acid level was around $13.63 \%$, and the stearic acid level was $4.46 \%$. In the present study, the lowest level of palmitic acid was in spring $(15.41 \%)$ and the highest was in winter $(20.72 \%)$. The lowest level of stearic acid was in winter $(14.75 \%)$ and the highest was in autumn (19.14\%). These two fatty acids are essential for they are dominant SFAs and both of their levels are higher than $N$. japonicus's levels in Nazeer et al. (2008)'s study. This can be either due to different characteristics of the sampling area or different affinities of the species when accumulating fatty acid contents. However, the levels of oleic acid, one of the dominant MUFAs, are significantly higher than the present study. For these two studies, $N$. japonicus's oleic acid level is $29.22 \%$, while $N$. randalli's highest level was in spring (7.98\%).

When Nazeer et al. (2008)'s study was compared to the present study regarding their EPA and DHA levels, they were surprisingly low, which were $1.4 \%$ and $0.49 \%$, respectively. In the present study, the highest EPA level was found at $5.34 \%$ in summer, and the highest DHA level was found at $23.00 \%$ in autumn.

Mohanty et al. (2016) also investigated the fatty acid profile of 39 food fishes from India, including Nemipterus japonicus. They found that the total lipid level of $N$. japonicus was $5.10 \%$ which is higher than both our study and Nazeer et al. (2008)'s. In Mohanty et al. (2016)'s study, the palmitic acid level was $23.00 \%$, the stearic acid level was $13.30 \%$, and the oleic acid level was $14.20 \%$. EPA level was found $6.60 \%$, and DHA level was found $26.50 \%$. The highest level of DHA was obtained from Rastrelliger kanagurta and it was $28.50 \%$. Moreover, $N$. japonicus's total omega 3 level was $33.70 \%$ and the total omega 6 level was $6.00 \%$. The highest level of total omega 3 was also obtained from $R$. kanagurta and it was $34.10 \%$, the highest level of total omega 6 was from Thunnus albacares and it was $15.60 \%$. In the present study, $N$. randalli's highest total omega 3 level was in autumn $(27.63 \%)$ and the highest total omega 6 level was in spring (4.79\%). These studies, which includes Nemipterus genus, show some similarities with the slight differences between their DHA, EPA, omega 3 and omega 6 levels.

For dietary consumption, fish is still one of the most essential sources for unsaturated fatty acids, particularly about EPA and DHA. Many studies show the health benefits of fish consumption. (Kinsella et al., 1977; Moffat and McGill, 1993). However, fish can not synthesize these long-chain $\omega$-3 PUFA. Fish feed on micro-organisms (such as algae) or on smaller fish that consume PUFAsynthesizing micro-organisms, thus acquiring long-chain

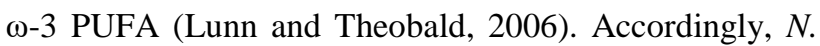
randalli feeds mainly on small benthic invertebrates such as polychaetes, crustaceans, cephalopods, and mollusks) and small fishes. (Otero et al., 2013). Associatively, it was observed that $N$. randalli contains high levels of $\omega-3$ PUFA in our study.

The effects of $\omega-3$ PUFAs for the treatment and prevention of cancer has been proved with the studies (Berquin, 2008). The researches revealed that the most crucial aspect of PUFAs for prevention of breast cancer was the ratio of $(\omega-3) /((\omega-6)$ PUFA rather than the absolute values of $(\omega-3)$ and $(\omega-6)$ separately. It can be concluded from the studies that $\sim 1: 1-1: 2$ ratio for $(\omega-3)$ / $(\omega-6)$ PUFA has the most preventive effect on the development and growth of cancer cells for breast cancer (Cowing and Saker, 2001). It was also investigated whether $\omega-3$ PUFAs have the infection and inflammation reduction effect (Klek et al., 2005). In our study, $(\omega-3) /((\omega-6)$ PUFA ratio was found in the range of 5.58-6.59 because $N$. randalli contains high levels of $\omega-3$. The consumption of PUFA-rich nutrition is also vital for the prevention of cardiac diseases. The minimum ratio of PUFA/SFA for human consumption is 0.45 (HMSO, 1994). This ratio was found in the range of $0.75-0.81$ in our study.

\section{Conclusion}

$N$. randalli has high potential in regards to total omega 3 levels, particularly about DHA. Despite slight differences, the values of total SFAs, MUFAs and PUFAs are similar in all seasons. No significant seasonal difference has been obtained between seasons for omega 36 , which are among the most valuable contents of $N$. randalli. In all seasons, $N$. randalli has high levels of ( $\omega$ $3) /(\omega-6)$ that have preventive effects on human health. Similarly, PUFA/SFA level was also higher than recommended levels in all seasons. All these results suggest that N.randalli is a crucial nutrient source at Mersin Bay.

\section{Conflict of interests}

The authors declare no conflict of interests.

\section{Acknowledgements}

This study was supported by the Research Fund of Mersin University in Turkey with Project Number: 20171-TP2-2185.

The summary of this work was presented in "IV. International Symposium on Traditional Foods from Adriatic to Caucasus" in 2018.

\section{References}

Berquin IM, Edwards IJ, Chen YQ. 2008. Multi-targeted therapy of cancer by omega-3 fatty acids. Cancer Letters, 269(2): 363-377.

Bligh EG, Dyer WJ. 1959. A rapid method of total lipid extraction and purification. Can. J. Biochem. Physiol., 37: 911-917.

Buchtova H, Smutna M, Vorlova L, Svobodova Z. 2004. Fatty Acid Composition in Diploid and Triploid Populations of Tench (Tinca tinca L.). Acta Vet. Brno, 73: 235. 
Chung SWC, Tong SK, Xiao Y, Ho YY. 2015. Methylmercury and long-chain n-3 fatty acids of 88 fish species commonly consumed in Hong Kong. Journal of Analytical Science and Technology, 6(5): 1-9.

Cowing BE, Saker KE. 2001. Polyunsaturated fatty acids and epidermal growth factor receptor/mitogen-activated protein kinase signaling in mammary cancer. Journal of Nutrition, 131(4): 1125-1128.

Friedland RP. 2003. Fish consumption and the risk of Alzheimer disease: is it time to make dietary recommendations. Arch Neurol., 60: 923-924.

Golani D. 2002. Lesepsian fish migration-characterization and impact on the Eastern Mediterranean Workshop on Lesepsian Migration Proceedings, 20-21 July 2002, Gökçeada, Turkey, Turkısh Marine Reserch Foundation, 1-9.

Golani D, Sonin O. 2006. The Japanese threadfin bream Nemipterus japonicus, a new Indo-Pacific fish in the Mediterranean. Journal of Fish Biology, 68: 940-943.

Gordon DT, Ratliff V. 1992. The implications of omega-3 fatty acids in human healty, Advences in seafood Biochemistry Composition and Quality, Ed. By George L. Flick, 406.

Gorga C. 1998. A new selected comments on lipids, Quality Assurance of Seafood Appendix 1, 245.

HMSO UK. 1994. Nutritional aspects of cardiovascular disease (report on health and social subjects no. 46), London.

Kinsella JE, Shimp JL, Mai J, Weihrauch J. 1977. Food components with potential therapeutic benefits: Then-3 PUFAs of fish oils. J. AOCS 54: 424-429.

Klek S, Kulig J, Szczepanik AM, Jedrys J, Kolodziejczyk P. 2005. The clinical value of paranteral immunonutrition in surgical patients Acta Chir. Belg., 105: 175-179.
Lambertsen H. 1978. Fresh Fish Quality and Quality Changes, H. Huss (ed.), FAO 17-19, Rome, 1998.

Leaf A, Weber PC. 1988. Cardiovascular effects of n-3 fatty acids, N. Engl. J. Med., 318: 549-557.

Lunn J, Theobald HE. 2006. The effects of dietary unsaturated fatty acids. In: British Foundation Nutrition Bulletin. No. 31. Blackwell, London, pp. 178-224.

Moffat CF, McGill AS. 1993. Variability of the composition of fish oils: Significance for the diet. Proc. Nutr. Soc., 52: 441456.

Mohanty BP, Ganguly S, Mahanty A, Sankar TV, Anandan R, Chakraborty K. 2016. DHA and EPA content and fatty acid profile of 39 food fishes from India. Hindawi Publishing Corporation, BioMed Research International, Vol. 2016.

Nazeer RA, Kumar NSS, Naqash SY, Radhika R, Kishore R, Bhatt SR. 2008. Lipid profiles of Threadfin bream (Nemipterus japonicus) organs. Indian Journal of Marine Science, 2009, 38 (4): 461-463.

Otero M, Cebrian E, Francour P, Galil Bi Savini D. 2013. "Monitoring Marine Invasive Species in Mediterranean Marine Protected Areas (MPAs) A strategy and practical guide for managers" (PDF). IUCN Centre for Mediterranean Cooperation, 105.

Ulbricht TLV, Southgate DAT. 1991. Coronary heart disease: seven dietary factors. Lancet, 338: 985-992.

Weihrauch, J.L.; Posati, L.P.; Anderson, B.A.; Exler, J., Lipid conversion factors for calculating fatty acid contents of foods. Journal of the American Chemists' Society 1975, 54: 3640.

Yücecan S, Baykan S. 1981. Food Chemistry, Food control and Analyses (in Turkish), M.E.B. Temel Ders Kitab1, İstanbul, 5, pp. 51-53. 